\title{
Influence of Heat Exchange Coefficients on Both Optimized Thermal Contact (OTCR) and Critical (CTCR) Resistances at the Contact Interface of a Flat Concrete Slab and a Rice Straw Board
}

\author{
Alassane Diene', Mamadou Lamine Lo', Abdoulaye Sene', Ablaye Fame1, Youssou Traore², \\ Seydou Faye2, Issa Diagne², Mamadou Babacar Ndiaye3 ${ }^{3}$, Gregoire Sissoko ${ }^{2,4}$ \\ ${ }^{1}$ Polytechnic School of Thiès, Thiès, Senegal \\ ${ }^{2}$ Laboratory of Semiconductors and Solar Energy, Physics Department, Faculty of Science and Technology, University Cheikh \\ Anta Diop, Dakar, Senegal \\ ${ }^{3}$ University Institute of Technology, University Iba Der THIAM of Thiès, Thiès, Sénégal \\ ${ }^{4}$ Groupe International de Recherche en Energie Renouvelable, Dakar, Senegal \\ Email: gsissoko@yahoo.com, gsissoko@yahoo.com
}

How to cite this paper: Diene, A., Lo, M.L., Sene, A., Fame, A., Traore, Y., Faye, S., Diagne, I., Ndiaye, M.B. and Sissoko, G. (2021) Influence of Heat Exchange Coefficients on Both Optimized Thermal Contact (OTCR) and Critical (CTCR) Resistances at the Contact Interface of a Flat Concrete Slab and a Rice Straw Board. Energy and Power Engineering, 13, 392-402. https://doi.org/10.4236/epe.2021.1312027

Received: November 8, 2021

Accepted: December 11, 2021

Published: December 14, 2021

Copyright $\odot 2021$ by author(s) and Scientific Research Publishing Inc. This work is licensed under the Creative Commons Attribution International License (CC BY 4.0).

http://creativecommons.org/licenses/by/4.0/ (c) (i) Open Access

\begin{abstract}
The study is carried out in imperfect contact with a concrete slab wall attached to a panel based on rice straw compressed in a dynamic frequency regime. We will propose the characterization of thermal insulation for thermal resistance of contact $(x=0.05 \mathrm{~m})$. The impact of heat exchange coefficients on the front face $(x=0 \mathrm{~m})$ and the rear face $(x=0.1 \mathrm{~m})$ on these resistors is shown.
\end{abstract}

\section{Keywords}

Concrete Slab, Rice Straw Board, Thermal Resistance of Contact, Frequency Dynamic

\section{Introduction}

The two necessary criteria of the thermal design [1] [2] [3] of the buildings are the protection of the occupants in an automatic and passive way, climatic factors: rain, wind, radiation, hot or cold walls and optimization of energy consumption [4] [5]. The designer must ensure that this consumption (production of hot or cold) remains within the limits set by the regulations and the financial 
possibilities of the occupants while ensuring a level of comfort defined by the client. The thermal insulation introduced by the different elements of the building envelope constitutes an important criterion of energy performance. It reduces heat loss, saves heating, limits greenhouse gas emissions and provides better living comfort [6].

For years, many researchers have been studying the characterization [7] and optimization of plant and agricultural materials [8] [9] for the energy performance of buildings. It is in these perspectives that we have turned to research by proposing the study of a concrete slab adjoining a compressed board of rice straw in imperfect contact. So in this study, we will try to determine the value of the optimal and critical thermal resistance [10]-[15].

\section{Presentation and Mathematical Modelling of the Insulation System: The Wall}

The diagram of the wall [12] [14] consisting of concrete and rice straw is shown in Figure 1. Temperatures $T_{1}$ and $T_{2}$ of the outdoor and indoor environments respectively are defined in a frequency dynamic regime with an excitatory pulsation $\omega$. The time is noted $t$.

The phenomenon of heat diffusion in the wall is governed by the equation of heat. In the absence of a heat source and sink, it is given by Equation (1) below:

$$
\frac{\partial^{2} T_{i}(x, t)}{\partial x^{2}}-\frac{1}{\alpha_{i}} \frac{\partial T_{i}(x, t)}{\partial t}=0
$$

$T(x, t)$ is the material temperature at a depth $x$ and time $t$.

$$
\alpha_{i}=\frac{\lambda_{i}}{\rho_{i} * c_{i}}
$$

$\alpha_{i}\left(\mathrm{~m}^{2} \cdot \mathrm{s}^{-1}\right)$ is the material's thermal diffusivity coefficient $i$.

$i=1$ or 2 for concrete slab or rice straw board respectively.

The boundary conditions [11] [12] [13] reflecting the different thermal exchanges at the interfaces and the initial condition are given by the equations below.

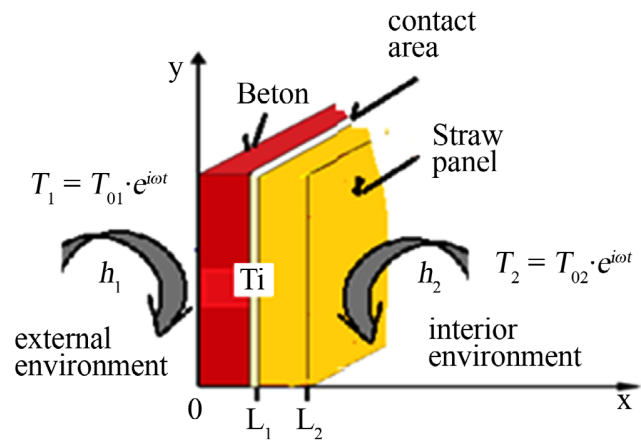

Figure 1. Study model diagrams. $T_{01}=45^{\circ} \mathrm{C} ; T_{02}=20^{\circ} \mathrm{C} ; T_{i}=23^{\circ} \mathrm{C} ; T_{i}$ is the initial wall temperature. $h_{1}$ and $h_{2}$ are the thermal exchange coefficients at the interface of the external and internal media, respectively. 


$$
\left\{\begin{array}{l}
\left.\lambda_{1} \frac{\partial T_{1}(x, t)}{\partial x}\right|_{x=0}=h_{1}\left[T_{1}(0, t)-T_{01} \cdot \mathrm{e}^{j \omega t}\right] \\
-\left.\lambda_{1} \frac{\partial T_{1}(x, t)}{\partial x}\right|_{x=l}=-\left.\lambda_{2} \frac{\partial T_{2}(x, t)}{\partial x}\right|_{x=l} \\
-\left.\lambda_{1} \frac{\partial T_{1}(x, t)}{\partial x}\right|_{x=l}=\frac{T_{1}(l, t)-T_{2}(l, t)}{R_{c}} \\
-\left.\lambda_{2} \frac{\partial T_{2}(x, t)}{\partial x}\right|_{x=L}=h_{2}\left[T_{2}(L, t)-T_{02} \cdot \mathrm{e}^{j \omega t}\right]
\end{array}\right.
$$

Considering that the wall is at an initial temperature $T_{i}$

$\bar{T}(x, t)$ the addition temperature is therefore:

$$
T_{i}(x, t)=\bar{T}_{i}(x, t)+T_{0 i} \text { Avec } i=1,2
$$

The expression of Equation (1) of heat becomes:

$$
\frac{\partial^{2}\left(\bar{T}+T_{i}\right)}{\partial x^{2}}-\frac{1}{\alpha} \frac{\partial\left(\bar{T}+T_{i}\right)}{\partial t}=0
$$

New boundary conditions become:

$$
\left\{\begin{array}{l}
\left.\lambda_{1} \frac{\partial \bar{T}_{1}(x, t)}{\partial x}\right|_{x=0}=h_{1}\left[\bar{T}_{1}(0, t)+T_{0 i}-T_{01} \cdot \mathrm{e}^{j \omega t}\right] \\
-\left.\lambda_{1} \frac{\partial \bar{T}_{1}(x, t)}{\partial x}\right|_{x=l}=-\left.\lambda_{2} \frac{\partial \bar{T}_{2}(x, t)}{\partial x}\right|_{x=l} \\
-\left.\lambda_{1} \frac{\partial \bar{T}_{1}(x, t)}{\partial x}\right|_{x=l}=\frac{\bar{T}_{1}(l, t)-\bar{T}_{2}(l, t)}{R_{c}} \\
-\left.\lambda_{2} \frac{\partial \bar{T}_{2}(x, t)}{\partial x}\right|_{x=L}=h_{2}\left[\bar{T}_{2}(L, t)+T_{0 i}-T_{02} \cdot \mathrm{e}^{j \omega t}\right]
\end{array}\right.
$$

The resolution of Equation (7) leads to the following solution:

$$
\begin{aligned}
\bar{T}_{1}\left(h_{1}, h_{2}, \alpha, \omega, x, t\right)= & {\left[A_{1} \sinh \left(\beta_{1} \cdot x\right)+A_{2} \cosh \left(\beta_{1} \cdot x\right)\right] \mathrm{e}^{j \omega t} } \\
\bar{T}_{2}\left(h_{1}, h_{2}, \alpha, \omega, x, t\right)= & {\left[A_{3} \sinh \left(\beta_{2} \cdot x\right)+A_{4} \cosh \left(\beta_{2} \cdot x\right)\right] \mathrm{e}^{j \omega t} } \\
\beta_{1} & =\sqrt{\frac{\omega}{2 \cdot \alpha_{1}}}(1+j) \\
\beta_{2} & =\sqrt{\frac{\omega}{2 \cdot \alpha_{2}}}(1+j)
\end{aligned}
$$

coefficients $A_{1}, A_{2}, A_{3}$ et $A_{4}$ are determined from boundary conditions.

\section{Results and Discussion}

The changes in temperature and heat flux density as a function of the thermal resistance of contact are described below under the influence of the heat exchange coefficients on the front and rear faces (yielding respectively Table 1 and Table 2). 
Table 1. Thermal resistance of critical and optimal contact under the influence of the heat exchange coefficient on the front face.

\begin{tabular}{|c|c|c|c|c|c|c|}
\hline \multicolumn{7}{|c|}{ CONTACT AREA OF BOTH MATERIALS } \\
\hline $\begin{array}{c}\text { Front face heat } \\
\text { exchange } \\
\text { coefficient } \\
\left(\mathrm{W} \cdot \mathrm{m}^{-2} \cdot \mathrm{K}^{-1}\right)\end{array}$ & $\begin{array}{c}\text { Maximal } \\
\text { thermal flow } \\
\left(\mathrm{W} \cdot \mathrm{m}^{-2}\right)\end{array}$ & $\begin{array}{c}\text { Critical } \\
\text { RTC } \\
\left(\mathrm{W} \cdot \mathrm{m}^{-2} \cdot \mathrm{K}^{-1}\right)\end{array}$ & $\begin{array}{l}\text { Critical interstitial } \\
\text { heat exchange } \\
\text { coefficient } \\
\left(\mathrm{W} \cdot \mathrm{m}^{-2} \cdot \mathrm{K}^{-1}\right)\end{array}$ & $\begin{array}{l}\text { Minimal } \\
\text { thermal flow } \\
\left(\mathrm{W} \cdot \mathrm{m}^{-2}\right)\end{array}$ & $\begin{array}{c}\text { Optimal } \\
\text { RTC } \\
\left(\mathrm{W} \cdot \mathrm{m}^{-2} \cdot \mathrm{K}^{-1}\right)\end{array}$ & $\begin{array}{c}\text { Optimal interstitial } \\
\text { heat exchange } \\
\text { coefficient } \\
\left(\mathrm{W} \cdot \mathrm{m}^{-2} \cdot \mathrm{K}^{-1}\right)\end{array}$ \\
\hline & 12.133 & $10^{-1.3}$ & 20 & 0.35 & $10^{1.3}$ & 0.05 \\
\hline & 16.319 & $10^{-1.3}$ & 20 & 0.471 & $10^{1.3}$ & 0.05 \\
\hline & 23.927 & $10^{-1.3}$ & 20 & 0.688 & $10^{1.3}$ & 0.05 \\
\hline 60 & 29.752 & $10^{-1.3}$ & 20 & 0.848 & $10^{1.3}$ & 0.05 \\
\hline 100 & 32.355 & $10^{-1.3}$ & 20 & 0.916 & $10^{1.3}$ & 0.05 \\
\hline
\end{tabular}

Table 2. Thermal resistance of critical and optimal contact under the influence of the heat exchange coefficient on the rear face.

\begin{tabular}{|c|c|c|c|c|c|c|}
\hline \multicolumn{7}{|c|}{ CONTACT AREA OF BOTH MATERIALS } \\
\hline $\begin{array}{l}\text { Rear face heat } \\
\text { exchange } \\
\text { coefficient } \\
\left(\mathrm{W} \cdot \mathrm{m}^{-2} \cdot \mathrm{K}^{-1}\right)\end{array}$ & $\begin{array}{l}\text { Maximal } \\
\text { thermal flow } \\
\left(\mathrm{W} \cdot \mathrm{m}^{-2}\right)\end{array}$ & $\begin{array}{c}\text { Critical } \\
\text { RTC } \\
\left(\mathrm{W} \cdot \mathrm{m}^{-2} \cdot \mathrm{K}^{-1}\right)\end{array}$ & $\begin{array}{l}\text { Critical interstitial } \\
\text { heat exchange } \\
\text { coefficient } \\
\left(\mathrm{W} \cdot \mathrm{m}^{-2} \cdot \mathrm{K}^{-1}\right)\end{array}$ & $\begin{array}{c}\text { Minimal } \\
\text { thermal flow } \\
\left(\mathrm{W} \cdot \mathrm{m}^{-2}\right)\end{array}$ & $\begin{array}{c}\text { Optimal } \\
\text { RTC } \\
\left(\mathrm{W} \cdot \mathrm{m}^{-2} \cdot \mathrm{K}^{-1}\right)\end{array}$ & $\begin{array}{c}\text { Optimal interstitial } \\
\text { heat exchange } \\
\text { coefficient } \\
\left(\mathrm{W} \cdot \mathrm{m}^{-2} \cdot \mathrm{K}^{-1}\right)\end{array}$ \\
\hline 0.1 & 31.693 & $10^{-1.3}$ & 20 & 0.918 & $10^{1.3}$ & 0.05 \\
\hline 0.5 & 29.675 & $10^{-1.3}$ & 20 & 0.928 & $10^{1.3}$ & 0.05 \\
\hline 1 & 28.456 & $10^{-1.3}$ & 20 & 0.941 & $10^{1.3}$ & 0.05 \\
\hline 5 & 27.938 & $10^{-1.3}$ & 20 & 0.991 & $10^{1.3}$ & 0.05 \\
\hline 10 & 28.476 & $10^{-1.3}$ & 20 & 1.005 & $10^{1.3}$ & 0.05 \\
\hline
\end{tabular}

Figure 2 shows that the temperature module at the contact zone evolves along a strip of contact thermal resistances. For values of $\mathrm{RTC} \leq 10^{2} \mathrm{~W} \cdot \mathrm{m}^{-2} \cdot \mathrm{K}^{-1}$ and $\mathrm{RTC} \geq 10^{2} \mathrm{~W} \cdot \mathrm{m}^{-2} \cdot \mathrm{K}^{-1}$, the temperature module hardly evolves corresponding to a quasi-static regime. For values of contact thermal resistance between $10^{-2}$ $\mathrm{W} \cdot \mathrm{m}^{-2} \cdot \mathrm{K}^{-1} \leq \mathrm{RTC} \leq 10^{2} \mathrm{~W} \cdot \mathrm{m}^{-2} \cdot \mathrm{K}^{-1}$, the temperature module varies considerably with the increase of the contact thermal resistance describing a dynamic velocity at the contact area.

For this purpose, the thermal flux density module (Figure 3) decreases with the increase in the thermal resistance of contact. The density of heat flux remains important for the large values of heat exchange coefficient on the front face due to the strong heat exchange between the external medium and the surface of the wall of the material leading to heat propagation by deep conduction. So according to the evolution of the thermal flux density at the contact area, the critical and optimal contact thermal resistance values describing the maximum and minimum flux density limit value at the contact area are defined.

We give below the value table of the critical and optimal thermal contact resistance under the influence of the heat exchange coefficient on the front face (Table 1). 


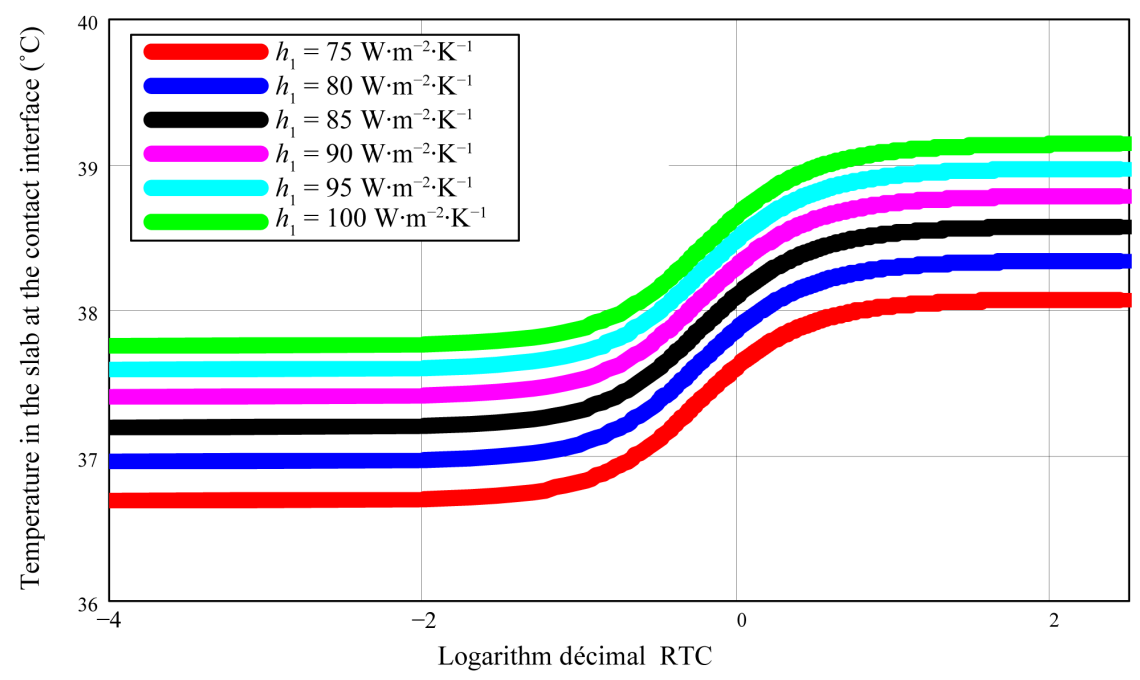

(a)

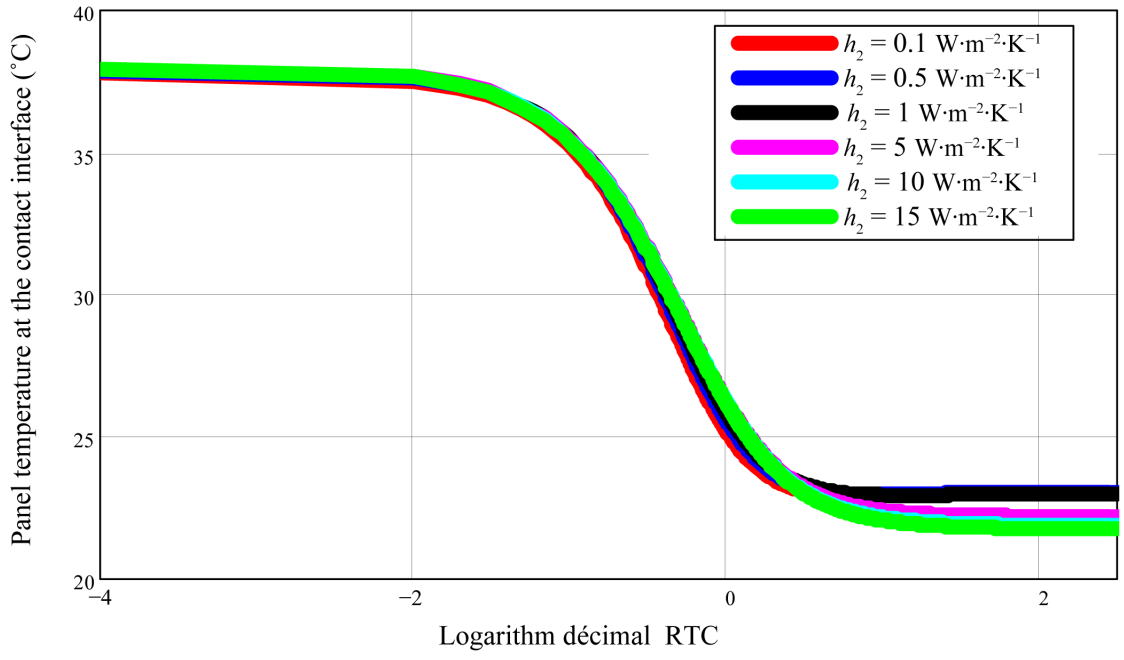

(b)

Figure 2. (a) Temperature variation as a function of the contact heat resistance. Influence of the exchange coefficient on the front face. $x=0.05 \mathrm{~m}, h_{2}=0.01 \mathrm{~W} \cdot \mathrm{m}^{-2} \cdot \mathrm{K}^{-1} \cdot \omega=2 \times 10^{-4}$ $\mathrm{rad} / \mathrm{s}$. (b) Temperature variation as a function of the contact heat resistance. Influence of the exchange coefficient on the rear side. $x=0.05 \mathrm{~m}, h_{2}=0.01 \mathrm{~W} \cdot \mathrm{m}^{-2} \cdot \mathrm{K}^{-1} \cdot \omega=2 \times 10^{-4}$ $\mathrm{rad} / \mathrm{s}$.

Below we will study the evolution of the temperature as a function of the depth by highlighting the effect of the exchange coefficient on the front and rear face in imperfect contact with an optimal thermal contact resistance value and critical (Table 1 and Table 2).

Figure 4 and Figure 5 shows that the temperature module decreases with increasing depth. The temperature module is important at the wall surface for large values of heat exchange coefficients on the front face. The heat exchange between the exterior and the surface of the wall thanks to the manpower, leads to conduction of the heat received on the front face of the first layer in the depth of the materials. At the level of the contact zone, a discontinuity of the temperature 


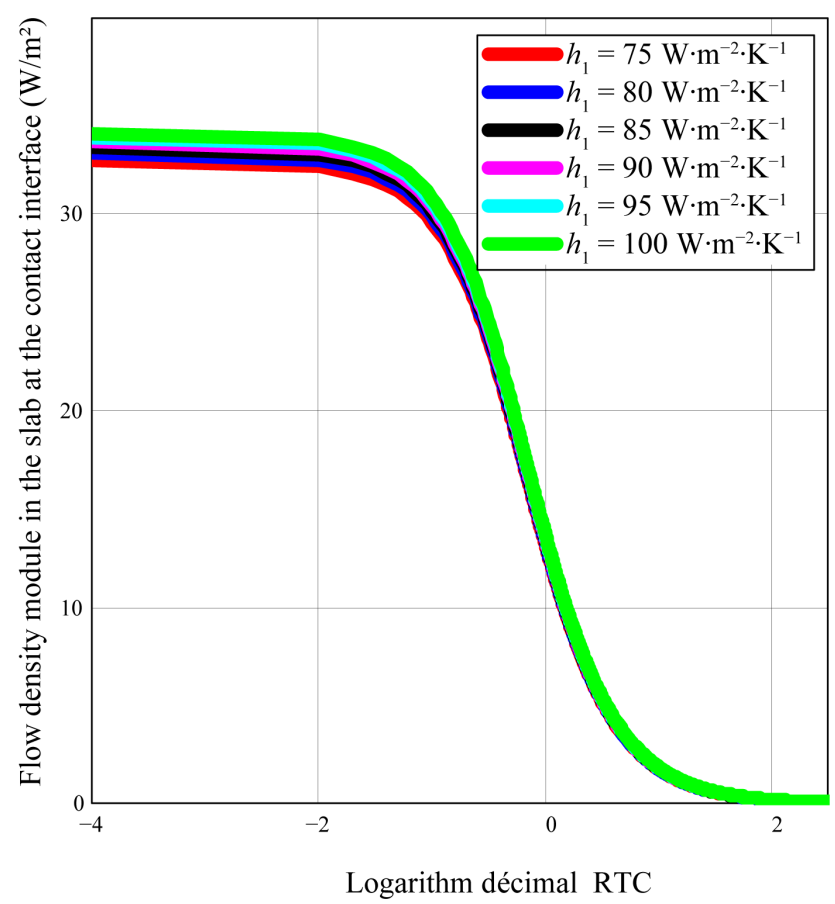

(a)

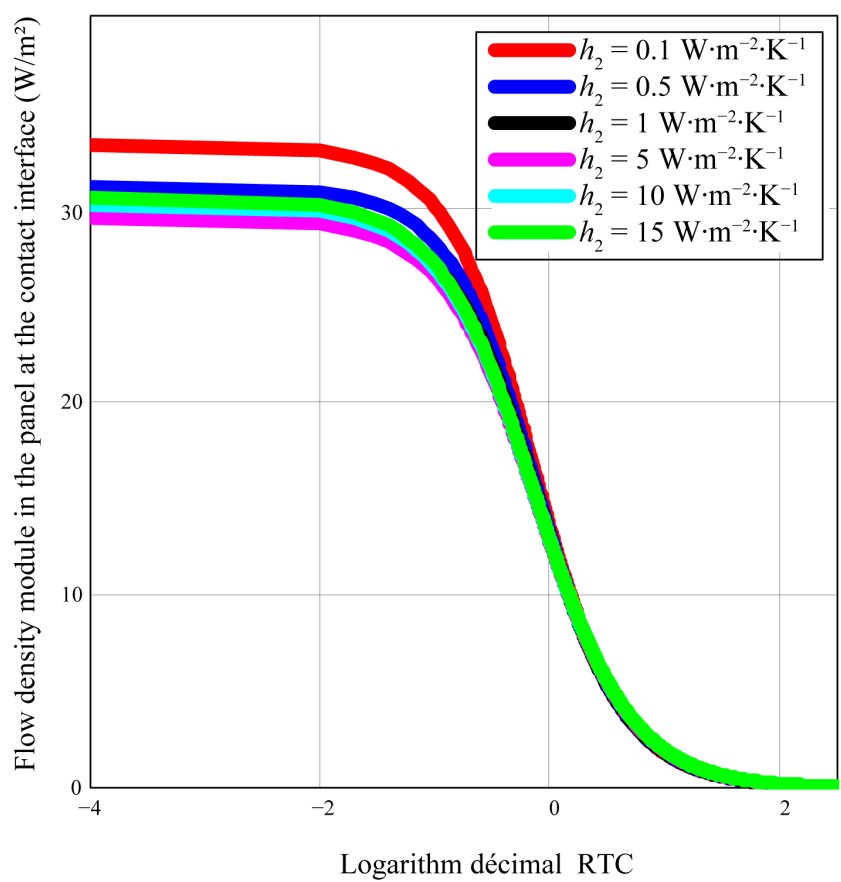

(b)

Figure 3. Evolution of heat flux density as a function of contact heat resistance. Influence of exchange coefficients on the front $(x=0 \mathrm{~m})$ and rear side $(x=0.05 \mathrm{~m}), \omega=2 \times 10^{-4}$ $\mathrm{rad} / \mathrm{s}$.

module is observed, thus generating a temperature gap that varies according to the increase of the exchange coefficient on the front face but remains invariant for values of exchange coefficients on the rear face. 


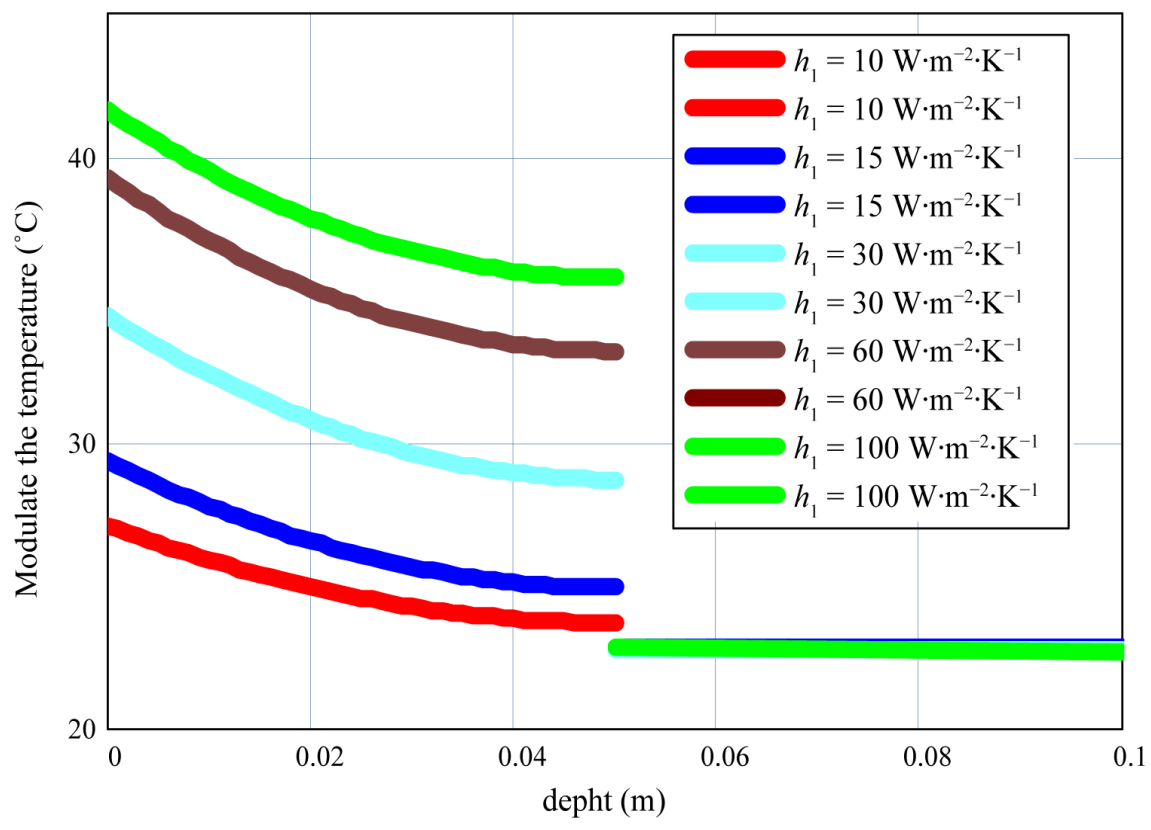

(a)

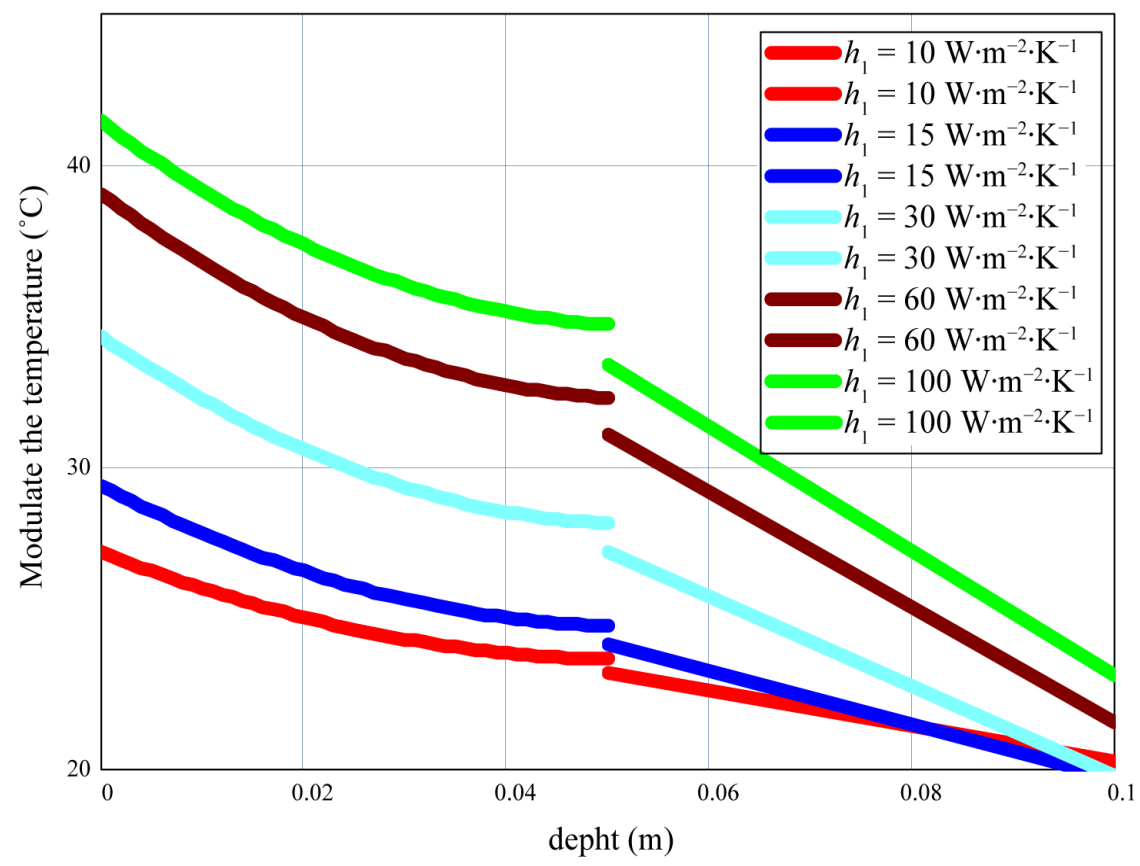

(b)

Figure 4. Temperature evolution through the wall as a function of its depth; Influences of the exchange coefficient on the front face $w=2 \times 10^{-4} \mathrm{rad} / \mathrm{s}, h_{2}=0.01 \mathrm{~W} \cdot \mathrm{m}^{-2} \cdot \mathrm{K}^{-1}$. (a) optimal contact resistance Rcop $=10^{1.3} \mathrm{~W} \cdot \mathrm{m}^{-2} \cdot \mathrm{K}^{-1}$. (b) critical contact resistance $\mathrm{Rcc}=10^{-1.3}$ $\mathrm{W} \cdot \mathrm{m}^{-2} \cdot \mathrm{K}^{-1}$.

Note that at the contact area level (Table 3 and Table 4) the gap is much more for a value of optimal contact thermal resistance thus promoting the insulating character of the contact zone with a value of the interstitial exchange coefficient $h_{0}$. 
Table 3. Development of the temperature gap at the contact zone for different values of the exchange coefficient on the front face.

\begin{tabular}{ccccc}
\hline $\begin{array}{c}\text { Front face heat } \\
\text { exchange } \\
\text { coefficient } h_{1} \\
\left(\mathrm{~W} \cdot \mathrm{m}^{-2} \cdot \mathrm{K}^{-1}\right)\end{array}$ & $\begin{array}{c}\text { Thermal flux } \\
\text { density } \\
\left(\begin{array}{c}\text { contact area }) \\
\left(\mathrm{W} \cdot \mathrm{m}^{-2}\right)\end{array}\right.\end{array}$ & $\begin{array}{c}\text { Contact wall } \\
\text { 1st layer } T_{1}\end{array}$ & $\begin{array}{c}\text { Contact wall } \\
\text { 2nd layer } T_{2}\end{array}$ & $\begin{array}{c}\text { Gap of } \\
\text { temperature } \\
\Delta\left({ }^{\circ} \mathrm{C}\right)=T_{2}-T_{1}\end{array}$ \\
\hline $\begin{array}{c}\mathrm{Rc}_{\mathrm{op}}=10^{1.3} \mathrm{~W}^{-1} \cdot \mathrm{m}^{2} \cdot \mathrm{K}, h 0_{\text {op }}=0.05 \mathrm{~W} \cdot \mathrm{m}^{-2} \cdot \mathrm{K}^{-1} \\
10\end{array}$ & 0.25 & 23,727 & 22,824 & $0.9^{\circ} \mathrm{C}$ \\
15 & 0.35 & 24,953 & 22,824 & $2.1^{\circ} \mathrm{C}$ \\
30 & 0.55 & 28,723 & 22,824 & $5.9^{\circ} \mathrm{C}$ \\
60 & 0.78 & 33,213 & 22,824 & $10.3^{\circ} \mathrm{C}$ \\
100 & 0.81 & 35,771 & 22,824 & $12.9^{\circ} \mathrm{C}$ \\
10 & $\mathrm{RcC}=10^{-1.3} \mathrm{~W}^{-1} \cdot \mathrm{m}^{2} \cdot \mathrm{K}, h 0_{\text {cc }}=20 \mathrm{~W} \cdot \mathrm{m}^{-2} \cdot \mathrm{K}^{-1}$ & \\
15 & 9.1624 & 23,653 & 23,24 & $0.41^{\circ} \mathrm{C}$ \\
30 & 12.582 & 24,752 & 24,134 & $0.61^{\circ} \mathrm{C}$ \\
60 & 19.486 & 28,152 & 27,179 & $0.97^{\circ} \mathrm{C}$ \\
100 & 25.719 & 32,296 & 31,072 & $1.22^{\circ} \mathrm{C}$ \\
& 28.896 & 34,722 & 33,405 & $1.31^{\circ} \mathrm{C}$ \\
\hline
\end{tabular}

Table 4. Evolution of the temperature gap at the contact zone for different values of the exchange coefficient on the rear face.

\begin{tabular}{|c|c|c|c|c|}
\hline $\begin{array}{l}\text { Heat exchange } \\
\text { coefficient on } \\
\text { the rear face } h_{2} \\
\left(\mathrm{~W} \cdot \mathrm{m}^{-2} \cdot \mathrm{K}^{-1}\right)\end{array}$ & $\begin{array}{c}\text { Thermal flux } \\
\text { density } \\
\text { (contact area) } \\
\left(\mathrm{W} \cdot \mathrm{m}^{-2}\right)\end{array}$ & $\begin{array}{l}\text { Contact wall } \\
\text { 1st layer } T_{1}\end{array}$ & $\begin{array}{l}\text { Contact wall } \\
\text { 2nd layer } T_{2}\end{array}$ & $\begin{array}{c}\text { Gap of } \\
\text { temperature } \\
\Delta T\left({ }^{\circ} \mathrm{C}\right)=T_{2}-T_{1}\end{array}$ \\
\hline \multicolumn{5}{|c|}{$\mathrm{Rc}_{\mathrm{op}}=10^{1.3} \mathrm{~W}^{-1} \cdot \mathrm{m}^{2} \cdot \mathrm{K}, h 0_{\mathrm{op}}=0.05 \mathrm{~W} \cdot \mathrm{m}^{-2} \cdot \mathrm{K}^{-1}$} \\
\hline 0.1 & 0.81 & 35,802 & 22,864 & $12.9^{\circ} \mathrm{C}$ \\
\hline 0.5 & 0.81 & 35,802 & 22,864 & $12.9^{\circ} \mathrm{C}$ \\
\hline 1 & 0.81 & 35,802 & 22,864 & $12.9^{\circ} \mathrm{C}$ \\
\hline 5 & 0.81 & 35,802 & 22,864 & $12.9^{\circ} \mathrm{C}$ \\
\hline 10 & 0.81 & 35,802 & 22,864 & $12.9^{\circ} \mathrm{C}$ \\
\hline \multicolumn{5}{|c|}{$\mathrm{Rcc}=10^{-1.3} \mathrm{~W}^{-1} \cdot \mathrm{m}^{2} \cdot \mathrm{K}, h 0_{\mathrm{cc}}=20 \mathrm{~W} \cdot \mathrm{m}^{-2} \cdot \mathrm{K}^{-1}$} \\
\hline 0.1 & 28.89 & 34,735 & 33,402 & $1.33^{\circ} \mathrm{C}$ \\
\hline 0.5 & 28.89 & 34,735 & 33,402 & $1.33^{\circ} \mathrm{C}$ \\
\hline 1 & 28.89 & 34,735 & 33,402 & $1.33^{\circ} \mathrm{C}$ \\
\hline 5 & 28.89 & 34,735 & 33,402 & $1.33^{\circ} \mathrm{C}$ \\
\hline 10 & 28.89 & 34,735 & 33,402 & $1.33^{\circ} \mathrm{C}$ \\
\hline
\end{tabular}




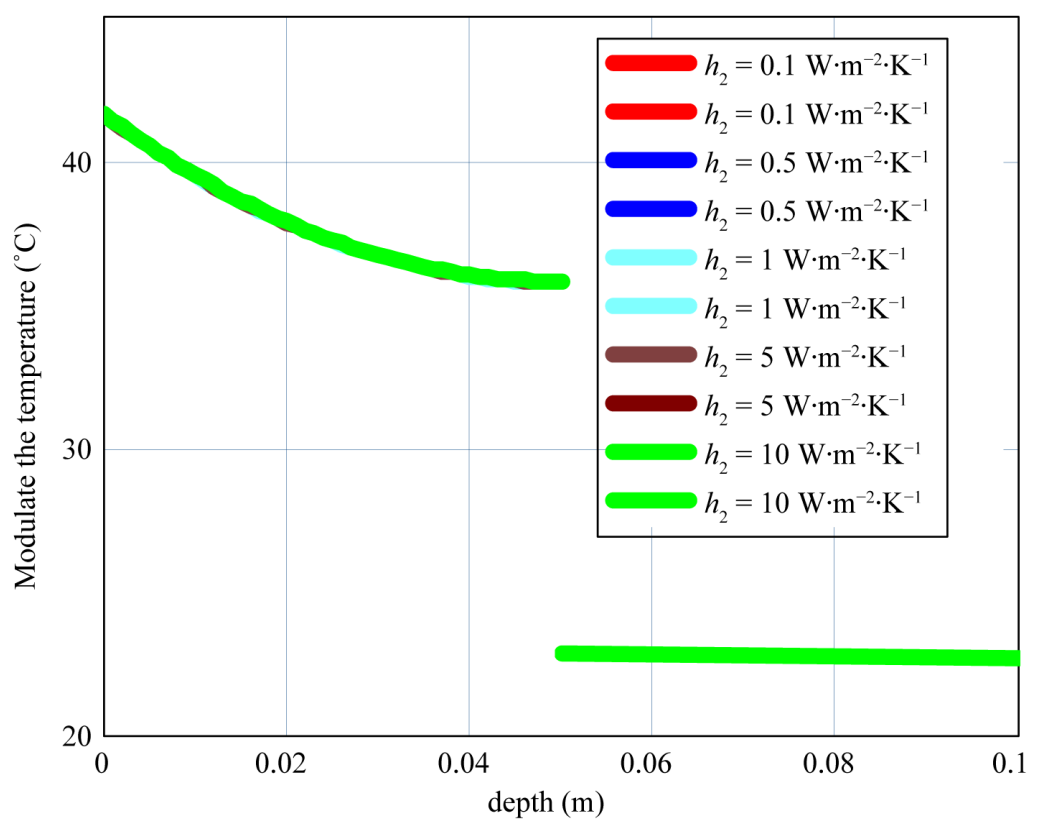

(a)

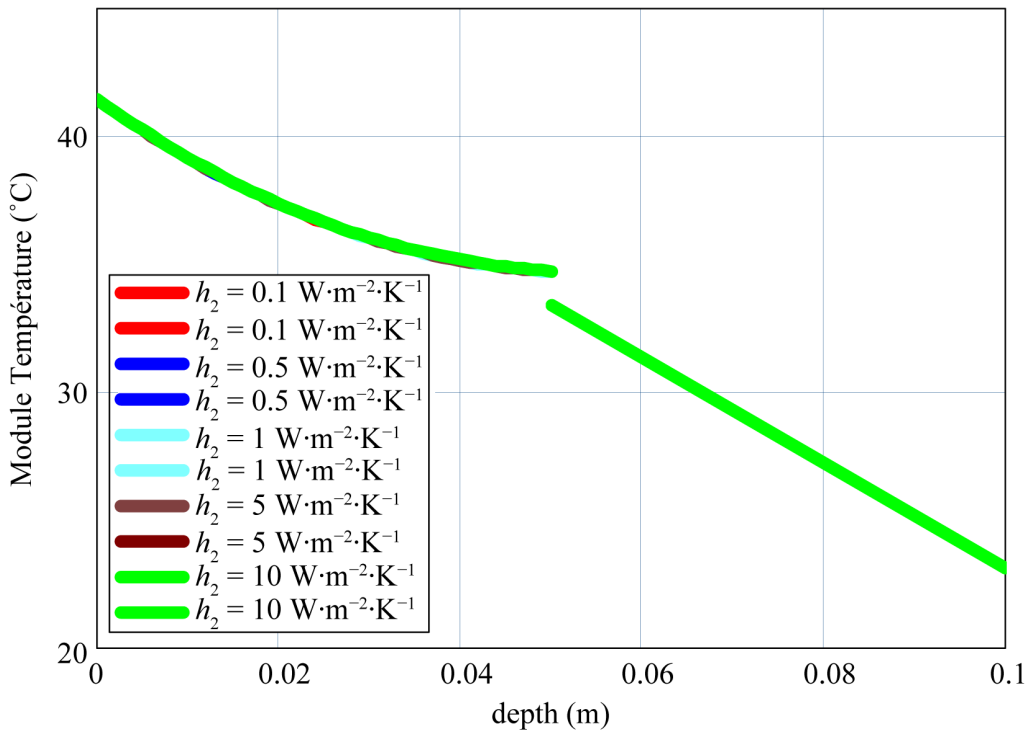

(b)

Figure 5. Evolution of the density of heat flow through the wall as a function of its depth; Influences of $h_{1} \cdot h_{2}=0.01 \mathrm{~W} \cdot \mathrm{m}^{-2} \cdot \mathrm{K}^{-1}$. (a) optimal contact resistance $\mathrm{RTcop}=10^{1.3}$ $\mathrm{W} \cdot \mathrm{m}^{-2} \cdot \mathrm{K}^{-1}$; (b) critical contact resistance $\mathrm{RTcc}=10^{-1.3} \mathrm{~W} \cdot \mathrm{m}^{-2} \cdot \mathrm{K}^{-1}$.

\section{Conclusion}

The study of the contact area between the concrete slab and the compressed panel shows the important role in the installation of two-layer materials. The ideal thermal resistance of contact characterizing a low heat exchange in this zone favors a significant drop in temperature leading to the existence of a conducto-convective flux. These heat losses in the contact area are essential to mitigate heat diffusion to the interior environment. 


\section{Conflicts of Interest}

The authors declare no conflicts of interest regarding the publication of this paper.

\section{References}

[1] Rojey, A. (2008) Energie et climat: Réussir la transition énergétique. Edition TECHNIP.

[2] Kremnev, V., Basok, B., Timoshchenko, A. and Tymchyshyn, S. (2018) Energy Saving in Construction by Wide Application of High-Quality Insulation Based on Basalt Fibers. Journal of Modern Physics, 9, 1724-1734.

http://www.scirp.org/journal/jmp https://doi.org/10.4236/jmp.2018.99108

[3] Silva de Andrade, F., Mobasher, B., Soranakom, C. and Toledo Filho, R.D. (2011) Effect of Fiber Shape and Morphology on Interfacial Bond and Cracking Behaviors of Sisal Fiber Cement Based Composites. Cement \& Concrete Composites, 33, 814-823. https://doi.org/10.1016/j.cemconcomp.2011.05.003

[4] Hejazi, M.S., Sheikhzadeh, M., Abtahi, M.S. and Zadhoush, A. (2012) A Simple Review of Soil Reinforcement by Using Natural and Synthetic Fibers. Construction and Building Materials, 30, 100-116.

https://doi.org/10.1016/j.conbuildmat.2011.11.045

[5] Janno, Y., Degiovanni, T.A. and Payet, G. (2009) Thermal Conductivity Measurement of Insulating Materials with a Three Layers Device. International Journal of Heat and Mass Transfer, 52, 1105-1111. https://doi.org/10.1016/j.ijheatmasstransfer.2008.09.017

[6] Gaye, S., Sissoko, G., Azilinon, D. and Adj, M. (2001) Qualification of Thermal Comfort in Humid Tropical Climates. ASME Journal, 70, 37-50.

[7] Voumbo, W., Gaye, S., Adj, M. and Sissoko, G. (2010) Characterization of the Thermo Physical Properties of Kapok. Research Journal of Applied Sciences, Engineering and Technology, 2, 143-148.

[8] Thiam, S.K.B., Ba, A., Ndiaye, M.B., Diagne, I., Traore, Y., Faye, S., Thiam, C., Traore, P.T., Fame, A. and Sissoko, G. (2020) One-Dimensional Study of Thermal Behavior of Typha Panel: Spectroscopy Characterization of Heat Exchange Coefficient on Front Face. Journal of Sustainable Bioenergy Systems, 10, 52-61.

https://www.scirp.org/journal/jsbs

[9] Brahim, M.S.O., Diagne, I., Ndiaye, M.B., Traore, Y., Faye, S., Thiam, C., Traore, P.T., Fame, A., Thiam, S.K.B. and Sissoko, G. (2020) Study at Two Dimensions of Thermal Transfer through a Fibers Panel Subjected to Climatic Constraints in Dynamic Frequency Regulations Established. Energy and Power Engineering, 12, 135-142. https://www.scirp.org/journal/paperinformation.aspx?paperid=100079 https://doi.org/10.4236/epe.2020.125010

[10] Traore, Y., Diagne, I., Sarr, C., Brahim, M.S.O., Diallo, A.K., Ly Diallo, H. and Sissoko, G. (2016) Influence of Thermal Exchange Coefficient on the Heat Retention Rate of a Concrete Wall Contiguous to a Thermal Insulation Tow-Plaster. ARPN Journal of Engineering and Applied Sciences, 11, 2835-2840.

[11] Mbengue, B., Diagne, I., Ndiaye, M.B., Traore, Y., Faye, S., Traore, P.T., Thiam, C., Fame, A., Thiam, S.K.B. and Sissoko, G. (2020) Influence of Excitation Period on Thermal Transfer of Tow-Plaster Thermal Insulation Plate Attached to Wall: Application to Cold Room. International Journal of Advanced Research, 8, 781-787. 
http://www.journalijar.com/article/32280

https://doi.org/10.21474/IJAR01/10841

[12] Thiam, C., Diene, A., Traore, Y., Ould Brahim, M.S., Diouf, A., Bah, O.M., Diagne, I. and Sissoko, G. (2017) Heat Distribution in a Multilayer in Dynamic Frequency Modulation: Influence of the Exciting Pulse, and the Thermal Exchange Coefficients. Journal of Scientific and Engineering Research, 4, 498-505.

[13] Ould Brahim, M.S., Diagne, I., Tamba, S., Niang, F. and Sissoko, G. (2011) Characterization of the Minimum Effective Layer of Thermal Insulation Material Tow-Plaster from the Method of Thermal Impedance. Research Journal of Applied Science, Engineering and Technology, 3, 338-344.

[14] Voumbo, M.L., Wereme, A. and Sissoko, G. (2010) Characterization of Locals Insulators: Sawdust and Wool of Kapok. Research Journal of Applied Sciences, Engineering and Technology, 2, 138-142.

[15] Ould Brahim, M.S., Tamba, S., Sarr, M., Diene, A., Diagne, I., Niang, F. and Sissoko, G. (2011) Evolution des coefficients globaux d'échange Thermique des matériaux kapok-plâtre et filasse-plâtre en régime dynamique fréquentiel. Revue des Energies Renouvelables, 14, 203-210. http://www.cder.dz 